\title{
MECHANISM OF INFECTION AND COLONIZATION OF RHIPICEPHALUS SANGUINEUS EGGS BY MERTARHIZIUM ANISOPLIAE AS REVEALED BY SCANNING ELETRON MICROSCOPY AND HISTOPATHOLOGY
}

\author{
Marcos Valerio Garcia ${ }^{1}$; Antonio Carlos Monteiro ${ }^{1 *}$; Matias Juan Pablo Szabo² ${ }^{2}$ Nancy Prette ${ }^{1}$; \\ Gervásio Henrique Bechara ${ }^{2}$
}

\begin{abstract}
${ }^{1}$ Laboratório de Microbiologia, Departamento de Produção Vegetal, Faculdade de Ciências Agrárias e Veterinárias, Universidade Estadual Paulista, Jaboticabal, SP, Brasil; ${ }^{2}$ Departamento de Patologia Animal, Faculdade de Ciências Agrárias e Veterinárias, Universidade Estadual Paulista, Jaboticabal, SP, Brasil.
\end{abstract}

Submitted: June 29, 2004; Returned to authors for corrections: July 11, 2005; Approved: November 07, 2005

\begin{abstract}
The present work aimed to verify the penetration pattern of the Metarhizium anisopliae fungus into Rhipicephalus sanguineus tick eggs, as well as the lesions occurred inside the egg. The fungus adherence and penetration were studied by scanning electron microscopy and the action of fungus in the internal tissues was evaluated through conventional histological sessions. For the observation of these events, experimental infections were performed in 11 groups of $R$. sanguineus eggs containing $25 \mathrm{mg}$ each. The eggs were bathed during 3 minutes under manual shaking in a $10^{8}$ conidia/mL suspension. The bath was performed only in the suspension vehicle for the control groups. The eggs were processed for histopathological analysis and scanning electron microscopy at the following times after infection: 1 and $18 \mathrm{~h}$ and one, two, three, four, five, six, seven, nine and eleven days. Relevant conidial germination was observed in $67 \%$ of eggs $18 \mathrm{~h}$ after inoculation and fungus penetrated in $92.6 \%$ of eggs 5 days after the infection. The pathogen extrusion occurred in $87 \%$ of eggs 7 days after infection, reaching $100 \%$ at the $9^{\text {th }}$ day. In the histopathological analysis, no lesions worthy of record was observed, however, it should be emphasized that significant reduction $(53.9 \%)$ of hatching from infected eggs was observed.
\end{abstract}

Key words: biological control, microbial control, entomopathogenic fungus, ticks

\section{INTRODUCTION}

Rhipicephalus sanguineus, a cosmopolitan tick is probably the tick of greatest worldwide distribution (17), and represent the sole species of the genus in Brazil (2). Its description has been frequently associated to the presence of it's host dog $(1,19,10,21)$, being adapted to pets in urban centers. $R$. sanguineus is a vector of several relevant pathogens for dogs, including agents of babesiosis, haemobartonelosis, hepatozoonosis and ehrlichiosis, some of them potentially transmissible to man. $(8,22)$. The control of this species of tick as a way of establishing better sanitary conditions to pets in general, remarkably to dogs is vital.

The control is currently performed by means of synthetic chemical products (acaricides). Recently, the resistance development of $R$. sanguineus to some active principles used in these formulations was verified (12). One of the alternatives to the use of acaricides is the biological control, especially with fungi, that showed to be an effective and promising technique, as previously verified $(6,13,15,16)$. $R$ sanguineus larvae bathed in suspensions with progressive concentrations of conidia of Beauveria bassiana demonstrated a decrease on the molt

*Corresponding Author. Mailing address: Laboratório de Microbiologia, Departamento de Produção Vegetal, Faculdade de Ciências Agrárias e Veterinárias, Universidade Estadual Paulista, Via de Acesso Prof. Paulo Donato Castellane, s/n. 14884-900, Jaboticabal, SP, Brasil. Tel.: (+5516) 3209-2652; Fax: (+5516) 3203-4275; E-mail: montecar@fcav.unesp.br 
percentage (3). The concentration of $10^{8} \mathrm{con} . / \mathrm{mL}$ of $B$. bassiana and $M$. anisopliae caused the death of $95 \%$ of larvae of $R$. sanguineus 20 days after infection (14), and M. anisopliae applied at different tick stadiums caused high mortality rate in all unfed instars (20). B. bassiana caused a reduction in percent hatching of larvae derived from infected eggs and in percent ecdysis of larvae and nymphs of $R$. sanguineus (18).

Only a few studies were conducted in order to assess the infection mechanisms of different phases of ticks life cycle by fungi, including eggs. The penetration and colonization of $R$. sanguineus engorged female by $M$. anisopliae was assessed (9), but there is a lack of information and knowledge with regard to the phenomenon or events concerning the pathogenicity mechanism of fungi on ticks. This work aimed to demonstrate the adhesion, germination, penetration and colonization of eggs of $R$. sanguineus by $M$. anisopliae as well as the lesions caused by fungus in the tick's egg.

\section{MATERIALS AND METHODS}

The E9 isolate of Metarhizium anisopliae obtained from Deois flavopicta (pasture spittlebug) was used, kept in stock culture in the Microbiology Laboratory of the Vegetal Production Department Faculty of Agrarian and Veterinary Sciences (FCAV) - São Paulo State University (Unesp), Jaboticabal City, São Paulo State, Brazil. The isolate was cultivated in Petri dishes containing potato-dextrose-agar medium (PDA), incubated at $27^{\circ} \mathrm{C}$ in the absence of light, for approximately 12 days.

The tick eggs collected until the $7^{\text {th }}$ day after the beginning of posture were obtained from the $R$. sanguineus colony kept in the Immunopathology Laboratory of the Animal Pathology Department, FCAV- Unesp. For the colony maintenance, the ticks were fed on rabbits free of previous contact with ticks. During feeding, the ticks were restricted to the hosts by transparent plastic chambers (4) fixed with non-toxic material (Britannia Adhesives P4104 Latex, England) to its depilated back. For the molt of the engorged instars as well as for its simple maintenance, the ticks were kept in an incubator at temperature of $28^{\circ} \mathrm{C}$ and relative humidity above $80 \%$.

For the infection, a suspension prepared in a $0.1 \%(\mathrm{v} / \mathrm{v})$ Tween $80^{\circledR}$ solution was used at the concentration of $10^{8}$ con./ $\mathrm{mL}(13,14,15,16,18)$, obtained from young colonies of fungus (conidial viability: $97.6 \%$ ). The $R$. sanguineus eggs were divided into 11 groups composed of $25 \mathrm{mg}$ each, in glass tubes. Each group was bathed with $1 \mathrm{ml}$ of the conidial suspension during 3 minutes, the excess liquid was removed using filter paper and the glass tubes were kept in incubator at $27^{\circ} \mathrm{C}$, absence of light and relative humidity above $80 \%$. The infected eggs were collected in 1 and $18 \mathrm{~h}$ and one, two, three, four, five, six, seven, nine and eleven days after treatment. In each time, a control group, bathed only with the suspension vehicle and another control group, no treated were also collected. After collecting in each pre-established time, the treated eggs were divided into two parcels: one addressed to the histopathological preparing and the other for the scanning electron microscopy.

The material addressed to the histopathological analysis was immersed in buffered formaldehyde solution for 12 to $24 \mathrm{~h}$. The fixed material was submitted to paraffin inclusion according to the histology routine techniques. Later, serial longitudinal cuts were performed in order to obtain the sections representative of both the infected egg and the control tissues. The sections were stained with hematoxylin-eosin stain for visualization of the tissue general alterations and Gomori Metanamine Stain (GMS), specific for fungi. For the histopathological analysis, only egg samples fully preserved were considered (morphologically intact).

The eggs addressed to the scanning electronic microscopy analysis were fixed in glutaraldehyde at 3\%, in potassiumphosphate buffer at $0.05 \mathrm{M}$ and $\mathrm{pH} 7.4$ for $72 \mathrm{~h}$. The eggs were washed in pure buffer solution for six consecutive times each 20 minutes. Later, the eggs were dehydrated in ethylic alcohol, dried in a $\mathrm{CO}_{2}$ critical point drier, recovered with gold particles $(35 \mathrm{~nm})$ and eletronmicrografies were made in JEOL JSM 5410 scanning electron microscopy, operating at $15 \mathrm{kV}$ (10).

\section{RESULTS AND DISCUSSION}

The histopathological analysis showed no conidia adhered to the eggs membrane in the period of $1 \mathrm{~h}$ after infection (Table 1) (Fig. 1 A). One may suppose that the conidia were washed away from eggs during samples processing. The smooth surface

Table 1. Absolute and percent values of eggs of Rhipicephalus sanguineus presenting adhesion, germination, penetration and extrusion of Metarhizium anisopliae, according to the postinfection time. Values between parenthesis indicate the total number of samples (eggs) analyzed.

\begin{tabular}{|c|c|c|c|c|}
\hline $\begin{array}{c}\text { Post-infection } \\
\text { Time }\end{array}$ & $\begin{array}{c}\text { Adhesion } \\
(\%)\end{array}$ & $\begin{array}{c}\text { Germination } \\
(\%)\end{array}$ & $\begin{array}{c}\text { Penetration } \\
(\%)\end{array}$ & $\begin{array}{c}\text { Extrusion } \\
(\%)\end{array}$ \\
\hline $\begin{array}{c}1 \text { hour } \\
(40)\end{array}$ & 0 & 0 & 0 & 0 \\
\hline $\begin{array}{l}18 \text { hours } \\
\text { (12) }\end{array}$ & - & $8 / 67 \%$ & 0 & 0 \\
\hline $\begin{array}{c}4 \text { days } \\
\text { (20) }\end{array}$ & - & - & $16 / 80 \%$ & 0 \\
\hline $\begin{array}{c}5 \text { days } \\
(27)\end{array}$ & - & - & $25 / 92.6 \%$ & 0 \\
\hline $\begin{array}{c}7 \text { days } \\
(23)\end{array}$ & - & - & $23 / 100 \%$ & $20 / 87 \%$ \\
\hline $\begin{array}{l}9 \text { days } \\
\text { (16) }\end{array}$ & - & - & - & $16 / 100 \%$ \\
\hline
\end{tabular}


of eggs and successive washings during histopathological processing may have contributed to such condition.

In test and control groups submitted to the histopathological analysis, no lesions worthy of record or embrionary phase the eggs were observed. However, in the control group where eggs were not processed for histopathology analysis and scanning electron microscopy, a high hatching $(95 \%)$ was observed, while in eggs from the test group, a relevant reduction of hatching (53.9\%) was observed. These observations suggest that morphological alterations (lesions) in eggs from the test group occurred after 11days. Biochemical and physiological alterations may have occurred during the period analyzed, however, with no morphological manifestation perceptable by microscopy.

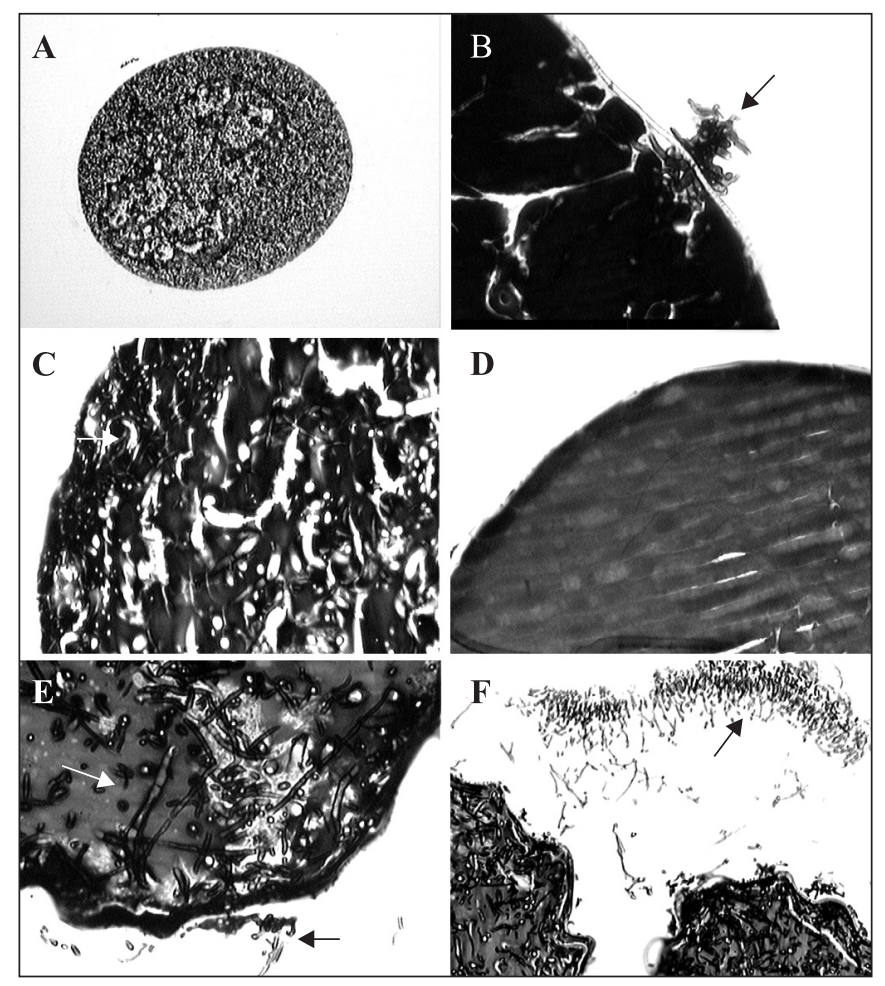

Figure 1. Photomicrographs of eggs of Rhipicephalus sanguineus tick in several times after experimental infection with conidial suspension of Metarhizium anisopliae. A absence of conidia on the egg surface $1 \mathrm{~h}$ after infection (G.M.S, magnificence of 10x); $\mathrm{B}$ - fungus penetration into egg (pointed by arrow) 4 days after infection (G.M.S, magnificence of 40x); C - egg colonization (pointed by arrow) 5 days after infection (G.M.S, magnificence of 40x); D - intact internal part of egg from control group (G.M.S, magnificence of 40x); E - egg colonization (pointed by arrow) and fungus extrusion (pointed by arrow) (G.M.S, magnificence of 40x) 9 days after infection; F - external development and conidiogenesis of fungus (pointed by arrow) in egg 9 days after infection (G.M.S, magnificence of 40x).
Report regarding susceptibility of eggs and larvae from $B$. microplus tick to the fungus $M$. anisopliae ratify a reduction on the hatching percentage that ranged from 3.3 to $66 \%$, according to the isolate and the fungus concentration used (5).

Observations performed $18 \mathrm{~h}$ after infection showed that $67 \%$ of infected eggs presented conidia germinated on their surface. Four days after infection, $80 \%$ of infected eggs were already colonized by fungus, reaching $92.6 \%$ at the $5^{\text {th }}$ day. The pathogen extrusion was observed 7 days after infection, when $87 \%$ of eggs presented the phenomenon, reaching $100 \%$ at the $9^{\text {th }}$ day, with a large amount of conidia adhered to the external surface of host (Table 1).

The fungus penetration inside the egg and the colonization were observed at the $4^{\text {th }}$ and $5^{\text {th }}$ days after infection. Fig. $1 \mathrm{~B}$ emphasizes the pathogen penetration into the egg membrane
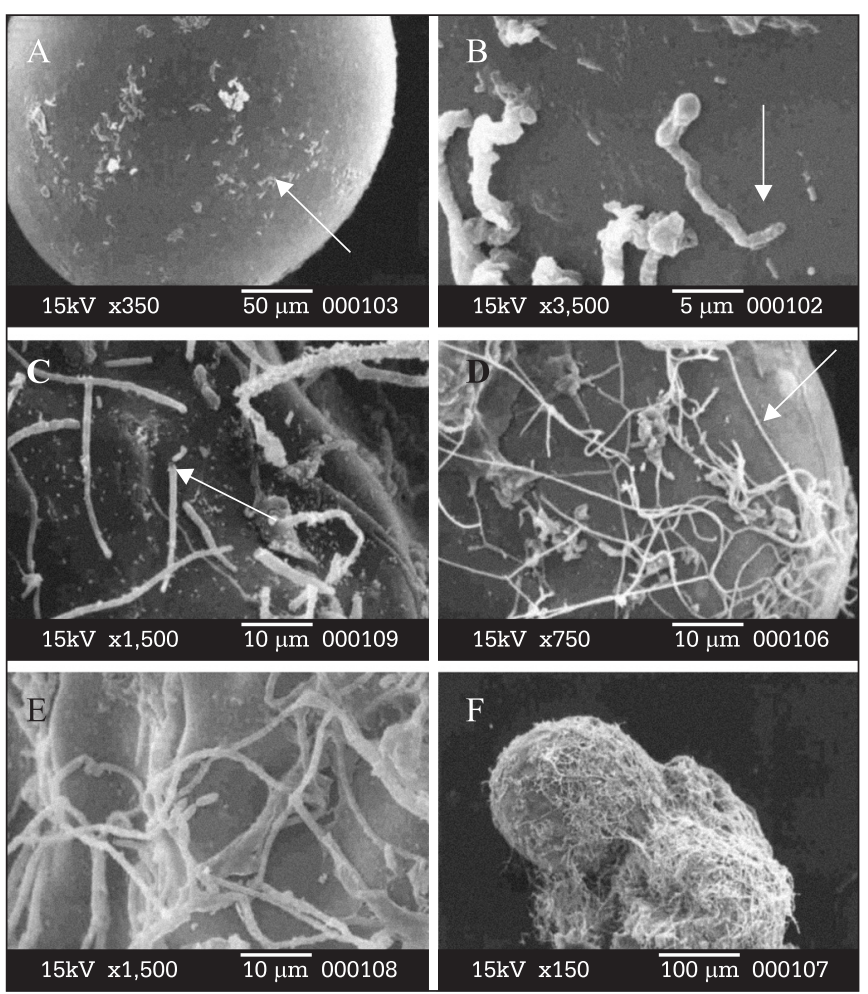

Figure 2. Scanning eletronmicrografies of eggs from Rhipicephalus sanguineus tick in several times after experimental infection with conidial suspension of Metarhizium anisopliae. A - conidia adhered to egg membrane (pointed by arrow) $1 \mathrm{~h}$ after infection; B - germination and apparent apressoria formation (pointed by arrow) $18 \mathrm{~h}$ after infection; C and D pathogen extrusion (pointed by arrow) and formation of hyphal bodies on the external egg surface (pointed by arrow) 4 and 5 days after infection; E and F - external development and sporulation of fungus on the egg surface. 
and Fig. $1 \mathrm{C}$ shows the egg fully colonized with a large amount of hyphal bodies. In samples from control group collected at the same time after infection, the presence of fungus inside the egg was not observed (Fig. 1 D). The histological cuts performed in eggs collected 9 days after infection emphasized the pathogen extrusion and conidiogenesis (Figs. $1 \mathrm{E}$ and F).

The eletronmicrografies of the infected eggs showed a large amount of conidia adhered to the external surface of eggs in a diffuse way (Fig. 2 A) $1 \mathrm{~h}$ after infection. The conidium germination and the formation of the germinative tube were evidenced through eletronmicrografies performed $18 \mathrm{~h}$ after infection (Fig. 2 B). Only few works, showing by means of scanning electron microscopy, the conidium adhesion and germination and the apressoria formation, can be found in literature, corroborating that $M$. anisopliae penetrates into $B$. microplus (7) and $R$. sanguineus (9) through the cuticle. The eletronmicrografies performed at the $4^{\text {th }}$ and $5^{\text {th }}$ days after infection showed the pathogen extrusion and wide hyphal bodies on the egg surface (Figs. $2 \mathrm{C}$ and D). The conidiogenesis occurred around the $9^{\text {th }}$ day after infection, being observed along the entire extension of eggs (Figs. $2 \mathrm{E}$ and F).

$M$. anisopliae is, in in vitro tests, pathogen of eggs of $R$. sanguineus. The conidium germination as well the penetration into the cuticle occurred quickly. The fungus colonizes massively the host internal tissues causing its death within a few days and consequently the non hatching of larvae. Intense micelial growth and high production of conidia on the egg surface complete the fungus development cycle.

\section{RESUMO}

\section{Mecanismo de infecção e colonização de ovos de Rhipicephalus sanguineus por Metarhizium anisopliae, revelado por microscopia eletrônica de varredura e histopatologia}

O presente trabalho teve como objetivo verificar a forma de penetração do fungo Metarhizium anisopliae em ovos do carrapato Rhipicephalus sanguineus, assim como as lesões infringidas no interior do ovo. A aderência e penetração do fungo foram estudadas por meio da microscopia eletrônica de varredura e a ação do fungo nos tecidos internos avaliada em secções histológicas convencionais. Para observação destes eventos, realizaram-se infecções experimentais em 11 grupos de ovos do $R$. sanguineus contendo $25 \mathrm{mg}$ cada. Os ovos foram banhados durante 3 minutos, sob agitação manual, em suspensão com concentração de $10^{8}$ conídios $/ \mathrm{mL}$. Nos grupos controle o banho foi realizado apenas no veículo da suspensão. Os ovos foram processados para análise histopatológica e microscopia eletrônica de varredura nos seguintes tempos após a infecção: 1 e 18h, e um, dois, três, quatro, cinco, seis, sete, nove e onze dias. Observou-se grande germinação de conídios em $67 \%$ dos ovos $18 \mathrm{~h}$ após a inoculação e o fungo penetrou em $92,6 \%$ dos ovos 5 dias após a infecção. A extrusão do patógeno ocorreu em $87 \%$ dos ovos 7 dias após a infecção, chegando a $100 \%$ no $9^{\circ}$ dia. Nas análises histopatológicas não foram observadas lesões dignas de nota, porem deve-se ressaltar que houve significativa redução $(53,9 \%)$ na eclosão a partir dos ovos infectados.

Palavras-chave: controle biológico, controle microbiano, fungo entomopatogênico, carrapato

\section{REFERENCES}

1. Aragão, H.B. Ixodidas brasileiros e de alguns paises limitrophes. Mem. Inst. Oswaldo Cruz, 31(4), 759-841, 1936.

2. Aragão, H.B.; Fonseca, F. Notas de Ixodologia. VII. Lista e chave para os representantes da fauna ixodológica brasileira. Mem. Inst. Oswaldo Cruz, 59(2), 115-130, 1961.

3. Barbosa, J.V.; Daemon, E.; Bittencourt, V.R.E.P.; Faccini, J.L.H. Efeitos de dois isolados do fungo Beauveria bassiana (Bals.) Vuill., sobre a muda larval e sobrevivência de ninfas de Rhipicephalus sanguineus (Latreille, 1806) (Acari: Ixodidae). Rev. Bras. Parasitol. Vet., 6, 53-56, 1997.

4. Bechara, G.H.; Heller-Haupt, A.; Varma, M.G.R.; Langi, A.O.; Trinder, P. K.E. Development of immunity to Rhipicephalus appendiculatus in hamsters (Mesocricetus auratus). Immunobiology, 4, 176, 1989.

5. Bittencourt, V.R.E.P.; Massard, C.L.; Lima, A.F. Ação do fungo Metarhizium anisopliae em ovos e larvas do carrapato Boophilus microplus. Rev. Univ. Rur., Sér. Ciên. Vida, 16(1-2), 41-47, 1994.

6. Bittencourt, V.R.E.P.; Peralva, S.L.F.S.; Souza, E.J.; Mascarenhas, A.G.; Alves, S.B. Efficacy of two isolates of Beauveria bassiana in engorged females of Boophilus microplus in the laboratory. Rev. Univ. Rur., Sér. Ciên. Vida, 19(1-2), 65-71, 1997.

7. Bittencourt, V.R.E.P.; Mascarenhas, A.G.; Faccini, J.L.H. The penetration of the fungus Metarhizium anisopliae on Boophilus microplus in experimental conditions. Ciên. Rur., 29(2), 351-354, 1999.

8. Estrada-Penã, A.; Jongejan, F. Ticks feeding on humans: a review of records on human-biting Ixodoidea with special reference to pathogen transmission. Exp. Appl. Acarol., 23, 685-715, 1999.

9. Garcia, M.V.; Monteiro, A.C.; Szabó, M.P.J. Colonização e lesão em fêmeas ingurgitadas do carrapato Rhipicephalus sanguineus causadas pelo fungo Metarhizium anisopliae. Ciên. Rur., 34(5), 1513-1518, 2004.

10. Labruna, M.B.; Pereira, M.C. Carrapato em cães. Clin. Vet., 6, 2432, 2001.

11. Maia, A.S.; Santos; J.M. A SEM technique for preparing biological control agents of nematodes in action. Acta Microsc., 6, 550-551, 1997.

12. Miller, R.J.; George, J.E.; Guerrero, F.; Carpenter, L.; Welch, J.B. Characterization of acaricide resistence in Rhipicephalus sanguineus (Latreille) (Acari: Ixodidae) collected from the Corozal Army Veterinary Quarentine Center, Panama. J. Med. Entomol., 38(2), 298-302, 2001.

13. Monteiro, A.C.; Fiorin, A.C.; Correia, A.C.B. Pathogenicity of isolates of Metarhizium anisopliae (Mestch.) Sorokin towards the cattle tick Boophilus microplus (Can.) (Acari: Ixodidae) under laboratory conditions. Rev. Microbiol., 29(2), 109-112, 1998.

14. Monteiro, S.G.; Bittencourt, V.R.E.P.; Daemon, E.; Faccini, J.L.H. Ação dos fungos Beauveria bassiana e Metarhizium anisopliae em larvas do carrapato Rhipicephalus sanguineus. Ciên. Rur., 28(3), 461-466, 1998 
15. Onofre, S.B.; Miniuk, C.M.; Barros, N.M.; Azevedo, J.L. Pathogenicity of four strains of entomopathogenic fungi against the bovine tick Boophilus microplus. Am. J. Vet. Res., 62(9), 1478-1480, 2001.

16. Paião, J.C.V.; Monteiro, A.C.; Kronka, S.N. Susceptibility of the cattle tick Boophilus microplus (Acari: Ixodidae) to isolates of the fungus Beauveria bassiana. W. J. Microbiol. Biotech., 17(3), 245-251, 2001.

17. Pegram, R.G.; Clifford, C.M.; Walker, J.B.; Keirans, J.E. Clarification of the Rhipicephalus sanguineus group (Acari, Ixodoidea, Ixodidae). II. R. sanguineus (Latreille, 1806) and related species. Syst. Parasitol., 10, 27-44, 1987.

18. Prette, N.; Monteiro, A.C.; Garcia, M.V.; Soares, V.E. Patogenicidade de isolados de Beauveria bassiana para ovos, larvas e ninfas ingurgitadas de Rhipicephalus sanguineus. Ciên. Rur., 35(4), 855-861, 2005.
19. Ribeiro, V.L.S.; Weber, M.A.; Fetzer, L.O.; Vargas, C.R. Espécies de prevalência das infestações por carrapatos em cães de rua da cidade de Porto Alegre, RS, Brasil. Ciên. Rur., 27(2), 285-289, 1997.

20. Samish, M.; Gindin, G.; Alekssev, E.; Glazer, I. Pathogenicity of entomopathogenic fungi to different developmental stages of Rhipicephalus sanguineus (Acari: Ixodidae). J. Parasitol., 38(6), 1355-1359, 2001.

21. Szabó, M.P.J.; Cunha, T.M.; Pinter, A.; Vicentini, F. Ticks (Acari: Ixodidae) associated with domestic dogs in Franca region, São Paulo, Brazil. Exp. Appl. Acarol., 25, 909-916, 2001.

22. Walker, J.B.; Keirans, J.E.; Horak, I.G. The Genus Rhipicephalus (Acari, Ixodidae). A guide to the brown ticks of the world. Cambridge University Press, Cambridge, 2000, 643p. 